\title{
Pivotal Role of TARC, a CC Chemokine, in Bacteria-induced Fulminant Hepatic Failure in Mice
}

\author{
Hiroyuki Yoneyama, ${ }^{\star \ddagger}$ Akihisa Harada, ${ }^{\star}$ Toshio Imai, ${ }^{\S}$ Masataka Baba, ${ }^{\S}$ Osamu Yoshie, $\|$ Yi Zhang, ${ }^{\star}$ Hidemitsu Higashi, \\ Masako Murai, ${ }^{\star \ddagger}$ Hitoshi Asakura, ${ }^{\ddagger}$ and Kouji Matsushima* \\ *Department of Molecular Preventive Medicine, School of Medicine, and CREST, The University of Tokyo, Tokyo 113, Japan; ${ }^{\ddagger}$ Third \\ Department of Internal Medicine, Niigata University School of Medicine, Niigata 951, Japan; ${ }^{\S}$ Shionogi Institute for Medical Science, \\ Osaka 566, Japan; and ${ }^{D}$ Department of Bacteriology, Kinki University School of Medicine, Osaka 589, Japan
}

\begin{abstract}
Thymus and activation-regulated chemokine (TARC) is a recently identified lymphocyte-directed $\mathrm{CC}$ chemokine which specifically chemoattracts $\mathrm{T}$ helper type $2 \mathrm{CD}^{+} \mathrm{T}$ cells in human. To establish the pathophysiological roles of TARC in vivo, we investigated whether a monoclonal antibody $(\mathrm{mAb})$ against TARC could inhibit the induction of hepatic lesions in murine model using Propionibacterium acnes and lipopolysaccharide (LPS). P. acnes-induced intrahepatic granuloma formation in the priming phase is essential to the subsequent liver injury elicited by a low dose of LPS. The priming phase appears to be dominated by Th1 type immune responses determined by the profile of chemokine and chemokine receptor expression. TARC was selectively produced by granuloma-forming cells, and CC chemokine receptor 4 (CCR4)-expressing $\mathrm{CD}^{+} \mathrm{T}$ cells migrated into the liver after LPS administration. In vivo injection of antiTARC mAb just before LPS administration protected the mice from acute lethal liver damage, which was accompanied by a significant reduction of both CCR4 mRNA expression and IL-4 production by liver-infiltrating $\mathrm{CD}^{+}{ }^{+} \mathrm{T}$ cells. Moreover, both TNF- $\alpha$ and Fas ligand expressions in the liver were decreased by anti-TARC treatment. These results suggest that recruitment of IL-4-producing CCR4 ${ }^{+}$ $\mathrm{CD}^{+} \mathrm{T}$ cells by granuloma-derived TARC into the liver parenchyma may be a key cause of massive liver injury after systemic LPS administration. (J. Clin. Invest. 1998. 102: 1933-1941.) Key words: chemokines • Th1 cells • Th2 cells • hepatitis • granuloma
\end{abstract}

\section{Introduction}

The microenvironment in areas of inflammation may provide optimal conditions for the emigration of lymphocytes from the blood $(1,2)$. Chemokines, a family of low molecular weight proteins that induce specific types of leukocyte chemotaxis, play essential roles in regulating the extravasation and tissue

Address correspondence to Prof. Kouji Matsushima, Department of Molecular Preventive Medicine, School of Medicine, The University of Tokyo, 7-3-1 Hongo, Bunkyoku, Tokyo 113-0033, Japan. Phone: 81-3-3812-2111 (3431); FAX: 81-3-5684-2297; E-mail: koujim@ m.u-tokyo.ac.jp

Received for publication 17 July 1998 and accepted in revised form 25 September 1998.

J. Clin. Invest.

(C) The American Society for Clinical Investigation, Inc. 0021-9738/98/12/1933/09 \$2.00

Volume 102, Number 11, December 1998, 1933-1941

http://www.jci.org accumulation of lymphocytes during immune and inflammatory responses $(1,3-6)$. Recent investigations have revealed the existence of a large number of novel lymphocyte-directed chemokines $(3,7-10)$. Among these $\mathrm{CC}$ chemokines, thymus and activation-regulated chemokine $(\mathrm{TARC})^{1}$ is the first $\mathrm{CC}$ chemokine to be shown to selectively chemoattract $\mathrm{T}$ lymphocytes (8). TARC was subsequently identified to be a specific ligand for $\mathrm{CC}$ chemokine receptor 4 (CCR4)-expressing cells (9), and induces chemotaxis of T cells, especially of the Th2 type $\mathrm{CD}^{+}$human $\mathrm{T}$ lymphocytes $(3,11,12$, and Imai, T., N. Nagira, S. Takagi, K. Kakizaki, M. Nishimura, J. Whang, P.W. Gray, K. Matsushima, and O. Yoshie, manuscript submitted for publication). However, the in vivo pathophysiological roles of TARC remain to be elucidated.

Fulminant hepatic failure (FHF) is a clinical syndrome characterized by sudden and severe impairment of liver function. Histopathological examination reveals diffuse intrahepatic infiltration by inflammatory cells with massive multilobular necrosis. Intrahepatic infiltrates are composed predominantly of T lymphocytes, and Fas ligand (FasL) expression is found in areas with lymphocytic infiltration (13). Heat-killed Propionibacterium acnes followed by a subsequent challenge with a low dose of LPS induces acute and massive liver injury, mimicking FHF (14). This liver injury model can be pathophysiologically classified into two phases: the early priming phase induced by $P$. acnes, and the late eliciting phase induced by LPS. At the priming phase, mononuclear cells infiltrate into the liver lobes, leading to granuloma formation. At the eliciting phase, inflammatory infiltrates are further increased, resulting in massive hepatocellular damage around granulomas due to necrosis and apoptosis. Although activated macrophages are considered to be one of the central effectors in this liver injury $(15,16)$, T lymphocyte infiltration is also presumed to be essential for the induction of liver damage (17-19). Indeed, during the priming phase, Th1 cells predominate in the liver in response to the synergistic action of IL-12 and IL-18 $(18,19)$.

It is likely that certain chemokines play roles in trafficking of effector $\mathrm{T}$ lymphocytes into inflamed areas of the liver. However, despite the observed massive lymphocyte infiltration, the identities of the chemokines that regulate lymphocyte infiltration and the subset of lymphocytes that act as effector cells have not been identified yet. We investigated here whether TARC was critically involved in lymphocytic infiltration into the liver and also evaluated the therapeutic efficacy

1. Abbreviations used in this paper: ALT, alanine transferase; CCR, CC chemokine receptor; CXCR, CXC chemokine receptor; FasL, Fas ligand; FHF, fulminant hepatic failure; GAPDH, glyceraldehyde3-phosphate dehydrogenase; IP-10, IFN- $\gamma$-inducible protein; MDC, macrophage-derived chemokine; Mig, monokine induced by IFN- $\gamma$; MIP-1, macrophage inflammatory protein-1; NKT, natural killer T cell; TARC, thymus and activation-regulated chemokine. 
of neutralizing anti-TARC $\mathrm{mAb}$ in preventing hepatic lesions in this murine model of FHF.

\section{Methods}

Mice. Specific pathogen-free female C57BL/6 (8-9 wk old) mice were obtained from CLEA Japan Inc. (Tokyo, Japan) and bred in a pathogen-free mouse facility of the Department of Molecular Preventive Medicine. All animal experiments complied with the standards set out in the guidelines of The University of Tokyo.

Reagents. P. acnes (ATCC 11828) was grown, heat killed, and lyophilized as described previously (14). LPS derived from Escherichia coli O55:B5 was purchased from Difco Laboratories (Detroit, MI).

$m A b s$. We have produced a hamster anti-mouse TARC mAb, 5H5-1-3 (Baba, M., T. Imai, and O. Yoshie, manuscript in preparation). 5H5-1-3 could completely inhibit the chemotactic activity of recombinant murine TARC on L1.2 cells transfected with murine CCR4 and did not immunologically cross-react against other tested murine $\mathrm{CC}$ chemokines including macrophage inflammatory protein$1 \alpha$ (MIP- $1 \alpha)$, MIP-1 $\beta$, JE, and macrophage-derived chemokine (MDC). This mAb 5H5-1-3 was used for in vivo administration and immunohistochemical studies.

Induction of liver injury. The mice were injected with $1 \mathrm{mg}$ of heat-killed P. acnes suspended in $100 \mu \mathrm{l}$ of PBS via the tail vein. $7 \mathrm{~d}$ later, they were given an intravenous injection of $0.3 \mu \mathrm{g}$ of LPS in 100 $\mu l$ of PBS. At the indicated time interval, at least five mice were killed at each time point. Approximately $1 \mathrm{ml}$ of blood was obtained by cardiac puncture under ether anesthesia and liver specimens were sampled. For the indicated experiments, $100 \mu \mathrm{g}$ of anti-TARC mAb or hamster gamma globulin (ROCKLAND, Gilbertsville, PA) was dissolved in $100 \mu \mathrm{l}$ of PBS. They were administered to mice intravenously $1 \mathrm{~h}$ before LPS challenge. Sera and liver specimens were obtained 1 or $6 \mathrm{~h}$ after LPS challenge. The survival rate was also determined at various time points after LPS challenge.

Histology. Liver specimens were fixed in $10 \%$ neutrally buffered formalin and were paraffin embedded. Deparaffinized sections (3 $\mu \mathrm{m})$ were stained with hematoxylin and eosin and analyzed by light microscopy.

Immunohistochemistry. Liver specimens were fixed for $4 \mathrm{~h}$ at $4^{\circ} \mathrm{C}$ in periodate-lysine-paraformaldehyde, washed for $4 \mathrm{~h}$ with PBS containing 10, 15, and $20 \%$ sucrose, embedded in Tissue-Tek O.C.T. compound (Miles, Elkhart, IN), frozen in liquid nitrogen, and cut by a cryostat into $7-\mu \mathrm{m}$-thick sections. After inhibition of endogenous peroxidase activity (20), the sections were incubated with a hamster anti-mouse TARC $\mathrm{mAb}$ or control hamster $\mathrm{IgG}$ at a concentration of $10 \mu \mathrm{g} / \mathrm{ml}$. They were treated sequentially with horseradish peroxidaseconjugated anti-hamster IgG (Southern Biotechnology Associates, Inc., Birmingham, AL). After visualization with 3,3'-diaminobenzidine (Wako Chemicals, Dallas, TX), slides were counterstained with Mayer's hematoxylin.

Chemokine and cytokine gene expression analysis in liver. Total RNA was isolated from liver specimens and sorted liver infiltrating $\mathrm{CD}^{+} \mathrm{T}$ lymphocytes using RNAzol ${ }^{\circledR}$ (BIOTECX LAB, Houston, TX), according to the manufacturer's instructions, and reverse transcribed into cDNA and amplified. The expressions of TARC, CCR4, CCR5, CXC chemokine receptor 3 (CXCR3), TNF- $\alpha$, and FasL were determined by a novel method for real time quantitative PCR using the ABI 7700 sequence detector system (PE Applied Biosystems, Foster City, CA) (21). The sense primer for TARC was 5'-CAGGAAGTTGGTGAGCTGGTATA-3', and the antisense primer was 5'-TTGTGTTCGCCTGTAGTGCATA-3'. The sense primer for CCR4 was $5^{\prime}$-TCTACAGCGGCATCTTCTTCAT-3', and the antisense primer was $5^{\prime}$-CAGTACGTGTGGTTGTGCTCTG-3'. The sense primer for CCR5 was 5'-CATCGATTATGGTATGTCAGCACC-3', and the antisense primer was 5'-CAGAATGGTAGTGTGAGCAGGAA-3'. The sense primer for CXCR3 was 5'-ATCAGCGCTTCAATGCCAC- $3^{\prime}$, and the antisense primer was $5^{\prime}$ -
TGGCTTTCTCGACCACAGTT- $3^{\prime}$. The sense primer for TNF- $\alpha$ was $5^{\prime}$-TCTCATTCCTGCTTGTGGC-3', and the antisense primer was $5^{\prime}$-GCTGGCACCACTAGTTGGTT-3'. The sense primer for FasL was $5^{\prime}$-AATCTGTGGCTACCGGTGGTA-3', and the antisense primer was 5'-TTCTGCAGGTGGAAGAGCTG-3'. The sense primer for glyceraldehyde-3-phosphate dehydrogenase (GAPDH) was 5'-AGTATGACTCCACTCACGGCAA-3', and the antisense primer was $5^{\prime}$-TCTCGCTCCTGGAAGATGGT-3'. The reaction master mix containing a cDNA sample was prepared according to the manufacturer's protocols to yield final concentrations of $1 \times$ PCR buffer A, $200 \mu \mathrm{M}$ dATP, dCTP, dGTP, and $400 \mu \mathrm{M}$ dUTP, $4 \mathrm{mM}$ $\mathrm{MgCl}_{2}, 1.25 \mathrm{U}$ AmpliTaq DNA polymerase, 0.5 U Amp-Erase uracil$\mathrm{N}$-glycosylase, and $200 \mu \mathrm{M}$ of each primer. The reactions also contained the following target hybridization probes $(100 \mu \mathrm{M}$ each). TARC probe was 5'-ATGCCATCGTGTTTCTGACTGTCCAGG3'. CCR4 probe was 5'-TGATCACGTGGTCAGTGGCTGTGTT3'. CCR5 probe was 5'-TACCTGCTCAACCTGGCCATCTCTGA$3^{\prime}$. CXCR3 probe was 5'-ATGCCCATATCCTAGCTGTTCTGCTGGTC-3'. TNF- $\alpha$ probe was $5^{\prime}$-AATTCGAGTGACAAGCCTGTAGCC-3'. FasL probe was 5'-TGGTTCTGGTGGCTCTGGTTGGAA-3'. GAPDH probe was 5'-AACGGCACAGTCAAG-

\section{Relative quantity of TARC mRNA}
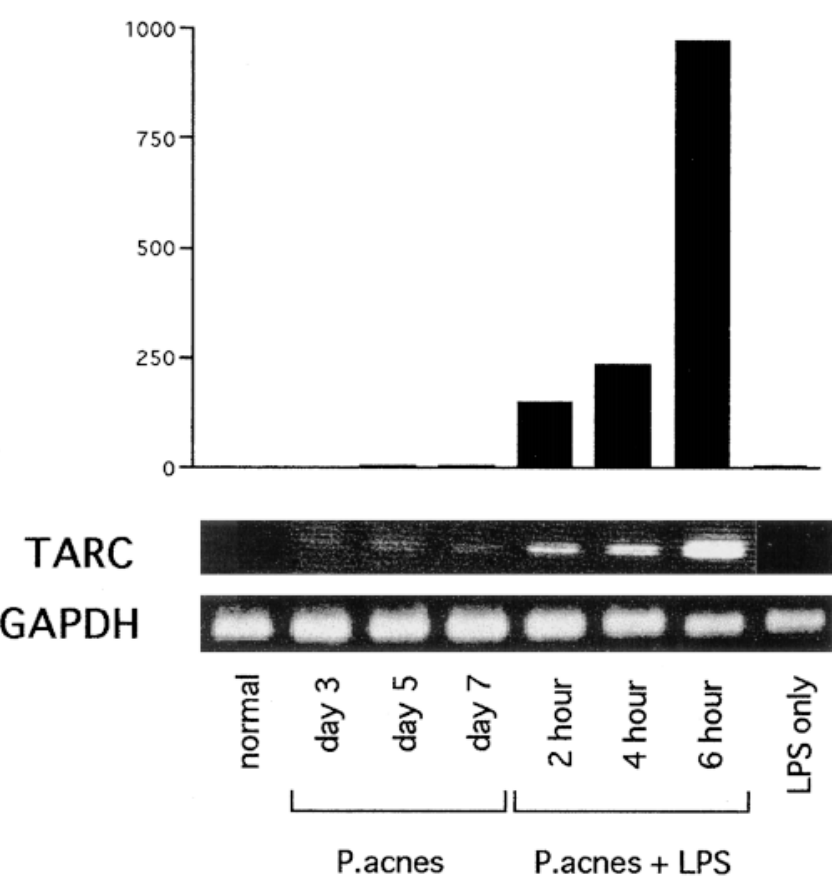

Figure 1. Induction of TARC expression in P. acnes- and sequential LPS-treated liver. Real time quantitative PCR analysis of TARC mRNA expression in the liver. Total RNA was isolated from liver tissues at the following time points: untreated, 3,5 , and $7 \mathrm{~d}$ after $P$. $a c$ nes treatment; 2,4 , and $6 \mathrm{~h}$ after sequential LPS injection; or $6 \mathrm{~h}$ after LPS injection without $P$. acnes priming. Total RNA was reverse transcribed with or without reverse transcriptase and amplified by real time quantitative PCR for TARC and GAPDH, according to the manufacturer's instructions. The amount of TARC was normalized to the level of GAPDH at each time point. A normalized TARC value of untreated liver was designated as the calibrator, and final relative quantity of TARC mRNA was expressed relative to the calibrator. The samples reverse transcribed without reverse transcriptase were never amplified, indicating the specificity of the PCR (data not shown). This result represents five independent experiments. PCR was performed in triplicate for each experiment. 
GCCGAGAAT-3'. The probe was labeled with a reporter fluorescent dye, FAM (6-carboxyfluorescein), at the $5^{\prime}$ end. The thermal cycling conditions included $50^{\circ} \mathrm{C}$ for $2 \mathrm{~min}$ and $95^{\circ} \mathrm{C}$ for $10 \mathrm{~min}$, followed by 40 cycles of amplification at $95^{\circ} \mathrm{C}$ for $15 \mathrm{~s}$, and $55^{\circ} \mathrm{C}$ for 1.5 min for denaturing, anneal-extension, respectively. The PCR products were also examined by $1.8 \%$ agarose gel electrophoresis. After ethidium bromide staining, bands were visible only at the expected molecular weights for each target mRNA product.

Preparation of liver infiltrating leukocytes, flow cytometric immunofluorescence analysis, and cell sorting. Liver-infiltrating leukocytes were prepared as described by Abo and co-workers (22), with some modifications. In brief, livers taken from six mice were minced, pressed through the stainless steel mesh, and suspended in 10\% FCS-DMEM. The cell suspension was treated with $33 \%$ Percoll containing $100 \mathrm{U} / \mathrm{ml}$ heparin and centrifuged at 2,000 rpm for $10 \mathrm{~min}$ to remove liver parenchymal cells. The pellet was treated with an RBC lysis solution, then washed three times in DMEM and resuspended in 10\% FCS-DMEM.

Flow cytometric immunofluorescence analyses of liver-infiltrating cells were performed as described previously (23). In brief, $4 \times 10^{5}$ cells were incubated with a PE-labeled anti-CD4 mAb and FITCconjugated anti-CD8 at $4^{\circ} \mathrm{C}$ for $30 \mathrm{~min}$ followed by two washes with $0.02 \%$ azide $/ 2.5 \%$ FCS-PBS solution. The natural killer $\mathrm{T}$ cells (NKT) were stained with FITC-conjugated anti-mouse CD3 mAb and biotinylated anti-mouse NK1.1 revealed by PE-conjugated streptavidin. All the mAbs and reagents used for immunostaining were obtained from PharMingen (San Diego, CA) unless otherwise indicated. The instrument compensation was set in each experiment using single-color stained samples and $\mathrm{CD}^{+} \mathrm{T}$ cells were sorted as

\section{A}
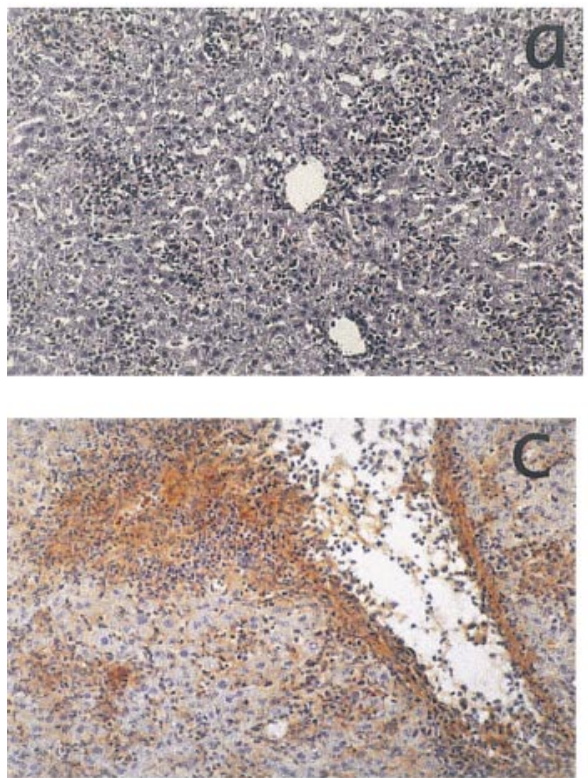

B
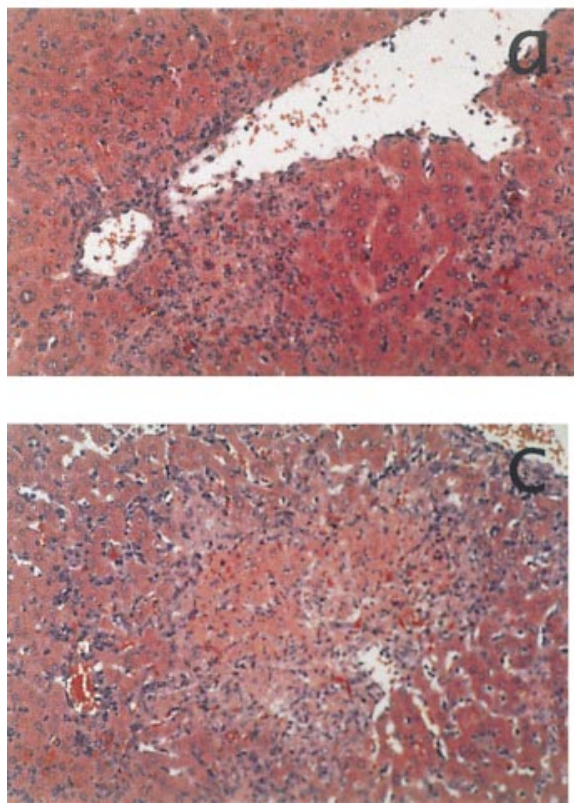
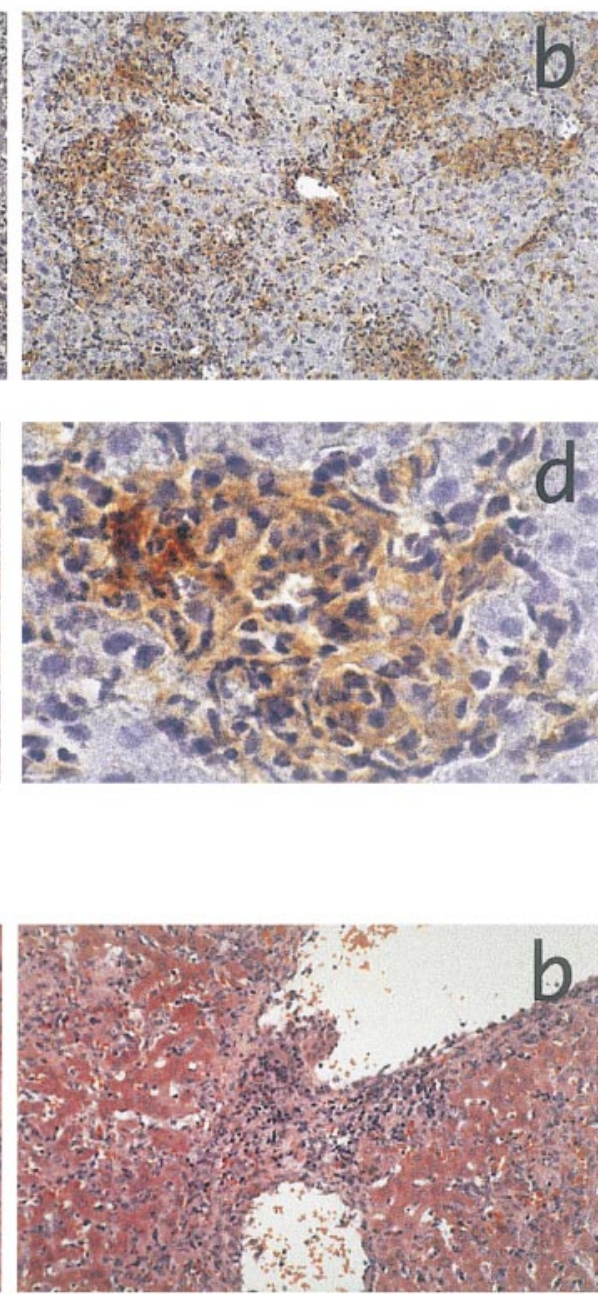

Figure 2. (A) Immunohistochemical detection of TARC in P. acnes- and LPS-administered liver. Sections of livers obtained from the following mice are shown. (a) $P$. acnes-primed mice at $7 \mathrm{~d}$. $(b-d)$ P. acnesprimed mice sequentially injected with LPS at $6 \mathrm{~h}$. After immunostaining using antiTARC $\mathrm{mAb}$, sections were observed at $\times 100(a-c)$ or $\times 400(d)$. TARC-positive (brown) cells are shown both in the granulomatous ( $b$ and $d$ ) and portal areas (c). $(B)$ Effect of anti-TARC $\mathrm{mAb}$ on the formation of hepatic lesion in P. acnes- and LPS-induced liver injury. Sections of livers obtained from the P. acnes-primed mice sequentially injected with LPS at $6 \mathrm{~h}$ and a group of mice injected with anti-TARC $\mathrm{mAb}(a$ and $d)$ or control $\mathrm{Ab}(b$ and $c) 1 \mathrm{~h}$ before LPS challenge. $\times 100$. 
described previously by an EPICS Elite cell sorter (Coulter Corp., Hialeah, FL).

Cytokine production by liver $C D 4^{+} T$ cells in vitro. Sorted liver $\mathrm{CD}^{+} \mathrm{T}$ lymphocytes $\left(10^{5} /\right.$ well per $\left.200 \mu \mathrm{l}\right)$ were incubated in $96-$ well plates for $24 \mathrm{~h}$ with medium, coated anti-CD3 mAb $(20 \mu \mathrm{g} / \mathrm{ml})$, or PMA $(50 \mathrm{ng} / \mathrm{ml})$ and ionomycin $(500 \mathrm{ng} / \mathrm{ml})$. The levels of IFN- $\gamma$ and IL-4 in each culture supernatant were measured by ELISA kits (Endogen, Cambridge, MA). The detection limits of the assay for IFN- $\gamma$ and IL-4 were 15 and $5 \mathrm{pg} / \mathrm{ml}$, respectively.

Determination of serum aminotransferase. Serum alanine transferase (ALT) levels were determined with a Fuji DRI-CHEM 5500V (Fuji Medical System, Tokyo, Japan) according to the manufacturer's instructions.

Statistical analysis. Results are expressed as the mean \pm SD. Statistical significance analyses were performed unless otherwise indicated by two-way ANOVA and multiple comparison methods by Scheffe. $P<0.05$ was accepted as statistically significant.

\section{Results}

Production of TARC by granulomas during systemic inflammatory responses. TARC mRNA was not detectable in the untreated liver, the $P$. acnes-treated liver, or the liver after the injection of a low dose of LPS into unprimed mice. However, TARC mRNA was detectable in the $P$. acnes-primed liver at $2 \mathrm{~h}$ after LPS challenge, and the expression levels were subsequently enhanced (Fig. 1).
To confirm the production of TARC protein and to identify the producing cells in the liver, immunohistochemical staining was performed next. There were no cells expressing TARC in the liver from either untreated (data not shown) or $P$. acnes-primed mice (Fig. $2 A$, panel $a$ ). In contrast, TARC was detected by anti-TARC mAb both in the granulomatous and portal areas of P. acnes- and LPS-treated liver (Fig. $2 A$, panels $b$ and $c$ ). TARC protein was detected mainly in the cytoplasm and on the surface of macrophage-like mononuclear cells present in granulomas (Fig. $2 A$, panel $d$ ) and portal tract. The control $\mathrm{Ab}$ did not stain the same tissue, indicating the specificity of the reaction (data not shown).

Anti-TARC $m A b$ protects the mice from acute lethal liver injury. To establish the biological role of TARC in causing liver injury, a neutralizing anti-TARC $\mathrm{mAb}$ was administered $1 \mathrm{~h}$ before LPS challenge. When the mice were treated with control Ab, $\sim 60 \%$ of $P$. acnes-primed mice $(n=28)$ died in response to subsequent LPS administration within $6 \mathrm{~h}$, and $>90 \%$ of the mice died within $12 \mathrm{~h}$ (Fig. $3 \mathrm{~A}$ ). In contrast, intravenous administration of anti-TARC $\mathrm{mAb}$ provided significant protection against lethality (Fig. $3 A$ ), and $>60 \%$ of the mice $(n=28)$ survived for $48 \mathrm{~h}$.

Moreover, at $6 \mathrm{~h}$ after subsequent LPS challenge, multilobular hepatic injury was observed in livers from $P$. acnesprimed mice, accompanied by a marked elevation of serum ALT levels. In contrast, treatment with anti-TARC mAb
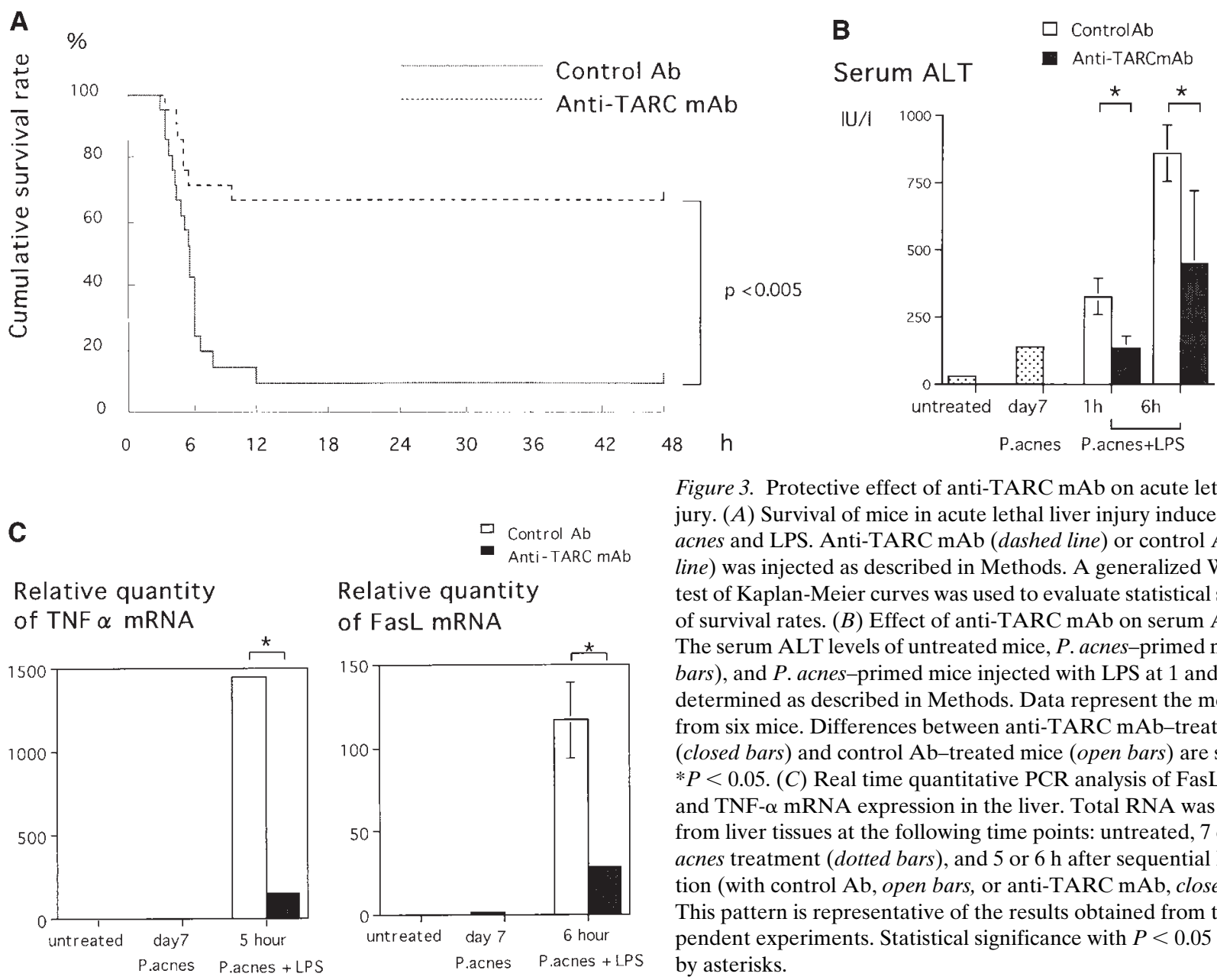

Figure 3. Protective effect of anti-TARC $\mathrm{mAb}$ on acute lethal liver injury. $(A)$ Survival of mice in acute lethal liver injury induced by $P$. acnes and LPS. Anti-TARC mAb (dashed line) or control Ab (solid line) was injected as described in Methods. A generalized Wilcoxon test of Kaplan-Meier curves was used to evaluate statistical significance of survival rates. $(B)$ Effect of anti-TARC mAb on serum ALT levels. The serum ALT levels of untreated mice, $P$. acnes-primed mice (dotted bars), and $P$. acnes-primed mice injected with LPS at 1 and $6 \mathrm{~h}$ were determined as described in Methods. Data represent the mean \pm SD from six mice. Differences between anti-TARC mAb-treated mice (closed bars) and control Ab-treated mice (open bars) are significant, $* P<0.05$. (C) Real time quantitative PCR analysis of FasL mRNA and TNF- $\alpha$ mRNA expression in the liver. Total RNA was isolated from liver tissues at the following time points: untreated, $7 \mathrm{~d}$ after $P$. acnes treatment (dotted bars), and 5 or $6 \mathrm{~h}$ after sequential LPS injection (with control Ab, open bars, or anti-TARC mAb, closed bars). This pattern is representative of the results obtained from three independent experiments. Statistical significance with $P<0.05$ is indicated by asterisks. 
caused a marked reduction of serum ALT levels compared with control Ab treatment (Fig. 3 B).

Because both TNF and Fas systems have been presumed to be involved in the process of hepatocellular damage during the eliciting phase (14-16), TNF- $\alpha$ mRNA and FasL mRNA expressions in the liver were analyzed by real time quantitative PCR. Neither TNF- $\alpha$ mRNA nor FasL mRNA was expressed in untreated or $P$. acnes-primed liver, but was highly induced by LPS injection after 5 and $6 \mathrm{~h}$, respectively. Anti-TARC treatment significantly reduced TNF- $\alpha$ mRNA and FasL mRNA expressions in the liver after LPS challenge compared with control Ab treatment (Fig. $3 C$ ).

Anti-TARC mAb inhibits LPS-induced mononuclear cell infiltration and multilobular necrosis in the P. acnes-primed liver. Histological examination also supported the protective effect of anti-TARC mAb. Mononuclear cells infiltrated into the hepatic lobes and formed numerous granulomas at $7 \mathrm{~d}$ after $P$. acnes treatment. Diffuse infiltration of mononuclear cells, mainly lymphocytes both in the granulomatous and portal areas, appeared after LPS challenge, culminating in multilobular coagulative necrosis and hepatocyte apoptosis (14). In contrast, at $6 \mathrm{~h}$ after LPS challenge, intravenous administration of anti-TARC mAb significantly blocked the increase in lymphocyte infiltration both in granulomatous and portal areas (Fig. $2 B$, panel $a$ ), whereas the control Ab did not (Fig. 2 $B$, panel $b$ ). Moreover, anti-TARC mAb reduced the liver necrosis in spite of the preexistence of granuloma (Fig. $2 \mathrm{~B}$, panel $d$ ), whereas the control Ab had no effect (Fig. $2 B$, panel $c$ ). These results suggested that anti-TARC $\mathrm{mAb}$ reduced liver injury by inhibiting lymphocyte trafficking to liver, especially to the granulomatous areas.

Anti-TARC mAb reduces LPS-induced $C D 4^{+} T$ cell infiltration into the P. acnes-primed liver. To identify liver-infiltrating mononuclear cells, we isolated liver leukocytes, counted the cells, and performed a flow cytometric analysis. $P$. acnes treatment increased the leukocyte number from $1.4 \times$ $10^{6} /$ liver to $9.5 \times 10^{6} /$ liver, and subsequent LPS challenge further increased the number of infiltrating cells to $12.2 \times 10^{6} \%$ liver by $6 \mathrm{~h}$ after treatment (Fig. $4 A$ ). We analyzed cell surface expression of $\mathrm{CD} 3, \mathrm{CD} 4, \mathrm{CD} 8$, and NK1.1 using a flowcytometer. Intrahepatic infiltrates consisted predominantly of $\mathrm{CD}^{+} \mathrm{T}$ cells. The absolute number of $\mathrm{CD}^{+} \mathrm{T}$ cells increased time dependently from $0.36 \times 10^{6} /$ liver to $4.9 \times 10^{6} /$ liver at $7 \mathrm{~d}$ after $P$. acnes treatment, and $8.1 \times 10^{6} /$ liver at $6 \mathrm{~h}$ after LPS challenge (Fig. $4 A$ ).

To elucidate whether anti-TARC mAb inhibited the $\mathrm{T}$ lymphocyte infiltration in the liver, we also determined the absolute number of liver-infiltrating $\mathrm{T}$ lymphocytes obtained from anti-TARC-treated liver. By $6 \mathrm{~h}$ after LPS challenge, anti-TARC mAb treatment markedly diminished the total number of liver leukocytes $\left(6.2 \times 10^{6} /\right.$ liver $)$ as well as the absolute number of $\mathrm{CD}^{+} \mathrm{T}$ cells $\left(3.6 \times 10^{6} /\right.$ liver $)$. It is noteworthy that during the LPS-induced eliciting phase the number of $\mathrm{CD}^{+} \mathrm{T}$ cells in anti-TARC $\mathrm{mAb}$ treated liver was almost
A

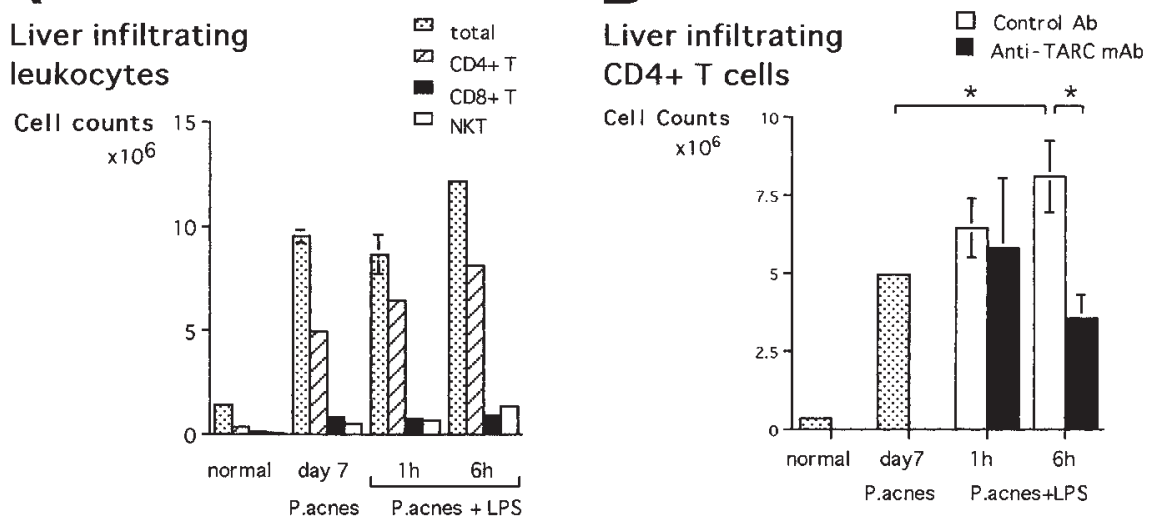

C

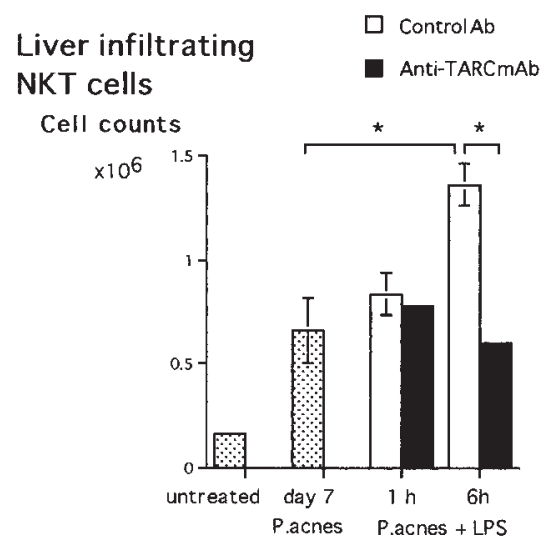

B
D

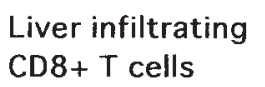

Cell counts

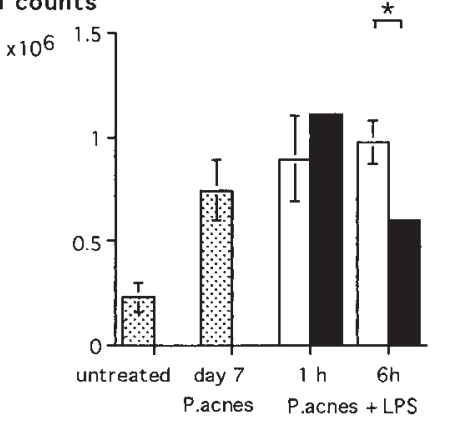

Figure 4. Effect of anti-TARC $\mathrm{mAb}$ on intrahepatic diffuse infiltration of mononuclear cells. $(A)$ The absolute number of $\mathrm{CD}^{+}$(hatched bars), $\mathrm{CD}^{+}$(closed bars), and NKT cells (open bars) was determined by multiplying the total leukocyte number (dotted bars) by the fraction of $\mathrm{CD}^{+}$, $\mathrm{CD}^{+}$, and $\mathrm{NK} 1.1^{+} \mathrm{CD}^{+}$population. Liver infiltrating leukocytes were prepared from untreated, $P$. acnes-primed, and sequentially LPS-treated mice. $(B-D)$ Effect of anti-TARC on liver-infiltrating $\mathrm{CD}^{+}{ }^{+} \mathrm{T}$ $(B)$, NKT $(C)$, and $\mathrm{CD} 8^{+} \mathrm{T}(D)$ cells. Liver-infiltrating $\mathrm{CD} 4^{+} \mathrm{T}, \mathrm{NKT}$, and $\mathrm{CD} 8^{+}$ T cells were prepared from untreated, $P$. acnes-primed (dotted bars) and P. acnesprimed mice injected with LPS at 1 and $6 \mathrm{~h}$ (with control Ab, open bars, or anti-TARC $\mathrm{mAb}$, closed bars). The mean $\pm \mathrm{SD}$ of six mice are shown here. Five independent experiments were performed. Statistical significance with $P<0.05$ is indicated by asterisks. 
equivalent to that in $P$. acnes-treated liver (Fig. $4 \mathrm{~B}$ ), indicating that anti-TARC $\mathrm{mAb}$ could block the increase in the number of liver-infiltrating $\mathrm{CD}^{+} \mathrm{T}$ cells during the eliciting phase.

$T A R C$ recruits $C C R 4$-expressing $C D 4^{+} T$ cells into the liver during the elicitation phase. To examine which subset of $\mathrm{CD}^{+}$ $\mathrm{T}$ cells was increased during the eliciting phase, we initially analyzed CCR expression by sorted liver $\mathrm{CD}^{+} \mathrm{T}$ cells. Total amounts of RNA of liver $\mathrm{CD}^{+}{ }^{+} \mathrm{T}$ cells were extracted immediately after sorting, and real time quantitative PCR was performed. Liver $\mathrm{CD}^{+}{ }^{+} \mathrm{T}$ cells at $7 \mathrm{~d}$ after $P$. acnes administration predominantly expressed CCR5 and CXCR3 mRNA, and CCR1, -2, -6, and -7 mRNAs were barely expressed. However, the expression levels of CCR5 and CXCR3 reached a peak at $7 \mathrm{~d}$ after $P$. acnes treatment and decreased within $6 \mathrm{~h}$ after LPS injection (Fig. $5 \mathrm{~A}$ ). In contrast, $\mathrm{CD}^{+} \mathrm{T}$ cells expressed significantly more CCR4 mRNA at the eliciting phase (Fig. $5 A$ ). Furthermore, anti-TARC $\mathrm{mAb}$ treatment selectively reduced CCR4 mRNA expression (Fig. $5 \mathrm{~B}$ ) and had no significant effect on CCR5 mRNA expression (data not shown). These results suggest that CCR4-expressing $\mathrm{CD} 4^{+} \mathrm{T}$ cells migrate de novo into the liver only after elicitation by LPS and the recruitment of CCR4-expressing $\mathrm{CD} 4^{+} \mathrm{T}$ cells was very likely regulated by TARC.

Anti-TARC mAb treatment decreases IL-4 production by liver-infiltrating $C D 4^{+} T$ cells. To examine which subset of $\mathrm{CD}^{+}{ }^{+} \mathrm{T}$ cell infiltration was diminished by anti-TARC treatment, we further analyzed IL-4 and IFN- $\gamma$ production by liverinfiltrating $\mathrm{CD}^{+}{ }^{+} \mathrm{T}$ cells. Sorted liver $\mathrm{CD}^{+}{ }^{+} \mathrm{T}$ cells were simply cultured, stimulated with an immobilized anti-CD3 mAb, or with PMA and ionomycin for $24 \mathrm{~h}$ in vitro, and were tested for IL-4 and IFN- $\gamma$ production. Liver $\mathrm{CD}^{+}{ }^{+} \mathrm{T}$ cells from untreated mice produced IL-4 and a small amount of IFN- $\gamma$. In contrast, the IL-4 level was decreased and the IFN- $\gamma$ level was dramatically increased by $\mathrm{CD}^{+} \mathrm{T}$ cells from $P$. acnes-primed liver (Fig. $6 \mathrm{~A}$ ), indicating that the priming by $P$. acnes was characterized by a Th1 type response. However, both IL-4 and IFN- $\gamma$ levels were increased by $\mathrm{CD}^{+} \mathrm{T}$ cells isolated from the liver after elicitation by LPS (Fig. $6 A$ ), and anti-TARC treatment downregulated IL-4 production, but upregulated IFN- $\gamma$ production (Fig. $6 \mathrm{~B}$ ). These results suggest that IL-4-producing $\mathrm{CD}^{+} \mathrm{T}$ cells were newly recruited into the liver at the eliciting phase, and anti-TARC treatment selectively reduced the recruitment of the IL-4-producing population.

Anti-TARC $m A b$ reduces Fas $L$ mRNA expression in liverinfiltrated $C D 4^{+} T$ cells, and inhibits recruitment of other potential effector cells into the liver. To investigate whether liver-infiltrating $\mathrm{CD}^{+} \mathrm{T}$ cells were actually involved in liver damage, we further examined FasL mRNA expression by sorted CD4 ${ }^{+} \mathrm{T}$ cells. Liver $\mathrm{CD}^{+}{ }^{+} \mathrm{T}$ cells expressed FasL mRNA at high levels $6 \mathrm{~h}$ after LPS injection, and anti-TARC mAb caused $\sim 70 \%$ reduction in FasL mRNA expression (data not shown). Furthermore, anti-TARC mAb treatment reduced the absolute number of NKT and $\mathrm{CD}^{+} \mathrm{T}$ cells (Fig. 4, $C$ and $D$ ), which are also potential effector cells in causing liver injury. However, CCR4 mRNA was not detected in these two populations during whole disease course (data not shown). Therefore, the reduction of NKT and $\mathrm{CD}^{+} \mathrm{T}$ cells might not be a direct effect of anti-TARC mAb. These results suggest that anti-TARC $\mathrm{mAb}$ can inhibit infiltration of the liver by effector $\mathrm{T}$ cells in both direct and indirect manners, resulting in protection from massive liver injury.

\section{Discussion}

We demonstrated previously that TNF receptor p55 was essential for granuloma formation and that TNF and Fas could independently induce hepatocellular apoptosis (14). However, neither the TNF- $\alpha$ - and FasL-expressing effector cells nor the molecules which are responsible for the migration of effector cells into the liver have been identified yet. Diffuse and massive lymphocyte infiltration was observed especially in the area of granuloma and portal tract (Fig. $2 B$, panels $b$ and $c$, and Fig. $4 \mathrm{~A}$ ). Accumulation of lymphocytes in the area of granulomatous inflammation involves interactions between tissue-spe-
A

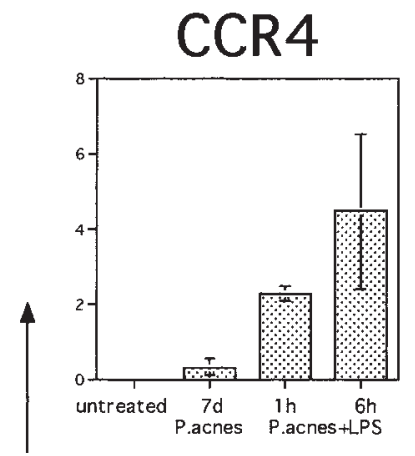

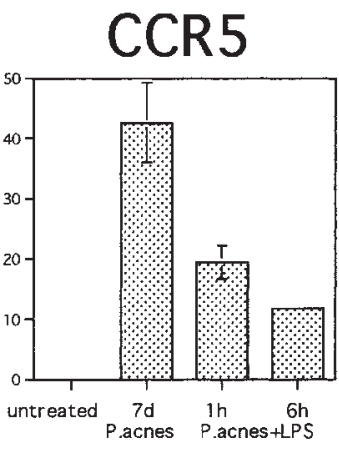

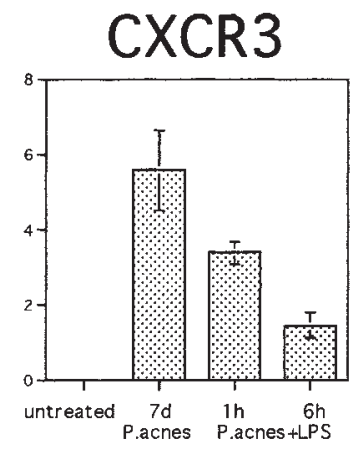

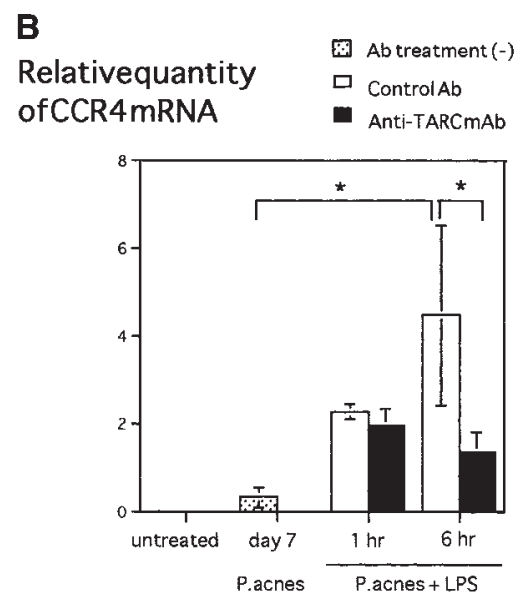

Relative quantity

Figure 5. Effect of anti-TARC mAb on the CCR4 mRNA-expressing CD4 ${ }^{+} \mathrm{T}$ cells in the liver after elicitation by LPS. ( $\left.A\right)$ Kinetics of CCR4, CCR5, and CXCR3 mRNA expression in liver CD4 ${ }^{+} \mathrm{T}$ cells. Sorted liver CD4 ${ }^{+} \mathrm{T}$ cells were prepared from untreated, $P$. acnes-primed, and $P$. acnes-primed mice injected with LPS at 1 and $6 \mathrm{~h}$. (B) Effect of anti-TARC mAb on CCR4 mRNA expression in liver CD4 ${ }^{+}$T cells. Sorted liver $\mathrm{CD}^{+}{ }^{+} \mathrm{T}$ cells were prepared from untreated, P. acnes-primed (dotted bars), and P. acnes-primed mice injected with LPS at 1 and $6 \mathrm{~h}$ (with control Ab, open bars, or anti-TARC mAb, closed bars). Real time quantitative PCR for CCR4-5 and CXCR3 was performed as described above. These patterns are representative of the results obtained from three independent experiments. Statistical significance with $P<0.05$ is indicated by asterisks. 

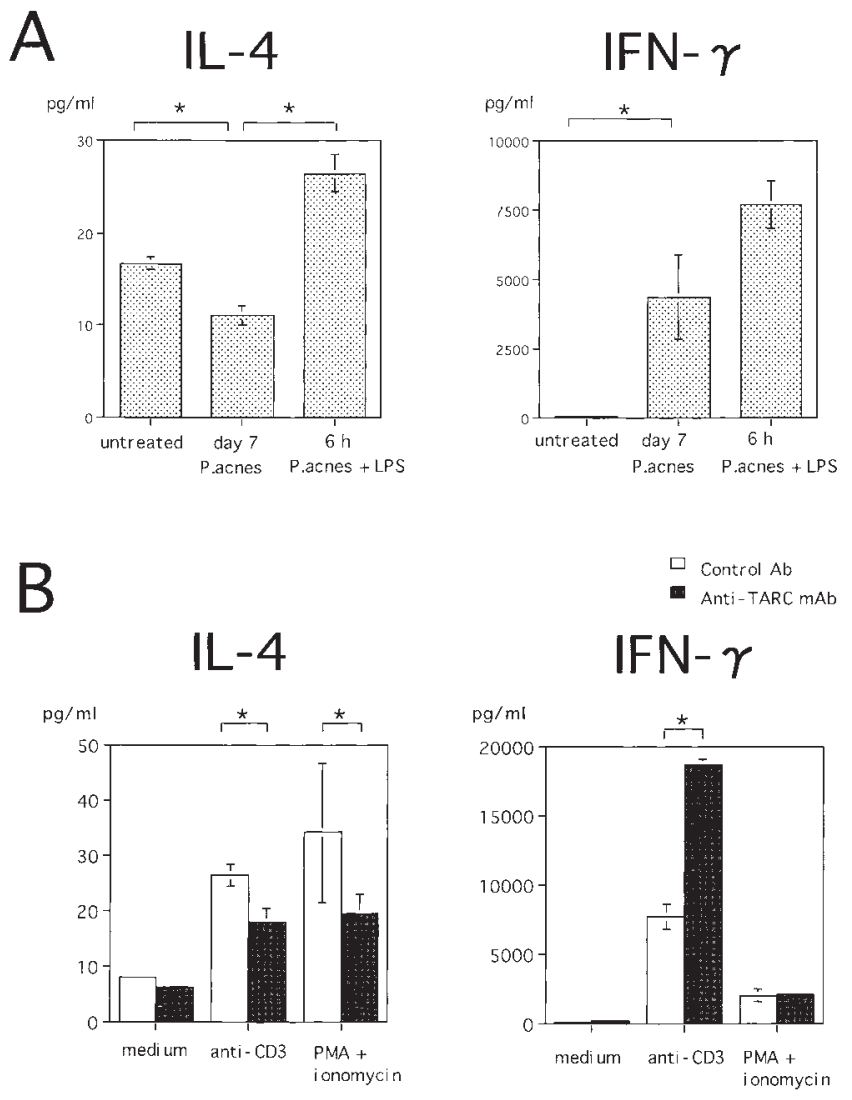

Figure 6. Decrease of IL-4 production by liver $\mathrm{CD}^{+} \mathrm{T}$ cells in antiTARC treated mice. $(A)$ Kinetics of IL- 4 and IFN- $\gamma$ production by liver $\mathrm{CD} 4^{+} \mathrm{T}$ cells. Liver $\mathrm{CD} 4^{+} \mathrm{T}$ cells were prepared from untreated, $P$. acnes-primed, and P. acnes-primed mice injected with LPS at $6 \mathrm{~h}$. Sorted liver $\mathrm{CD}^{+}{ }^{+} \mathrm{T}$ cells $\left(10^{5} /\right.$ well $)$ were cultured on anti-CD3 Abcoated 96-well plates for $24 \mathrm{~h}$. Culture supernatants were tested for IL-4 and IFN- $\gamma$ production as described in Methods. $(B)$ Effect of anti-TARC $\mathrm{mAb}$ on IL-4 and IFN- $\gamma$ production by liver $\mathrm{CD} 4^{+} \mathrm{T}$ cells. Liver $\mathrm{CD}^{+} \mathrm{T}$ cells were prepared from $P$. acnes-primed mice injected with LPS at $6 \mathrm{~h}$ (with control Ab, open bars, or anti-TARC $\mathrm{mAb}$, closed bars). Sorted liver $\mathrm{CD}^{+}{ }^{+} \mathrm{T}$ cells $\left(10^{5} /\right.$ well $)$ were incubated with medium alone, coated anti-CD3 Ab $(20 \mu \mathrm{g} / \mathrm{ml})$, or PMA $(50 \mathrm{ng} / \mathrm{ml})$ and ionomycin $(500 \mathrm{ng} / \mathrm{ml})$ for $24 \mathrm{~h}$. IL-4 and IFN- $\gamma$ production was measured by ELISA. Results are representative of three separate experiments, and statistical significance with $P<0.05$ is indicated by an asterisk.

cific microenvironment and specific subsets of lymphocytes (1, 2 ). To identify the molecules and mechanisms of induction of massive injury in this model, we investigated the immune interaction between granuloma-forming cells and LPS-induced $\mathrm{T}$ lymphocytes, and the role of chemokines in this interaction.

The recently identified lymphocyte-directed CC chemokine, TARC, is transiently expressed in mitogen-stimulated peripheral blood mononuclear cells, constitutively expressed at high levels in the thymus, and weakly expressed in the lung, colon, and small intestine, but not in the liver (8). However, immunohistochemical studies demonstrated that TARC protein was unexpectedly produced after LPS challenge in the $P$. acnes-primed liver. During the eliciting phase, focal multilobular necrotic areas were observed around granulomas, and TARC was present at high levels in these granulomatous areas. TARC-positive cells were also detected in bile duct epi- thelial cells in the portal area and scattered in the parenchyma (Fig. $2 A$ ). These results suggest a possibility that TARC is involved in the process of $\mathrm{T}$ helper lymphocyte migration into the inflamed granulomatous areas. When activated $\mathrm{T}$ lymphocytes arrive in the granulomatous area, they are capable of initiating and causing the hepatic damage through their interaction with macrophage-like cells and/or possibly dendritic cells as antigen-presenting cells or hepatocytes.

Accumulating evidence indicates that $\mathrm{T}$ lymphocytes as well as macrophages are involved in the priming phase of this liver injury model (17-19). P. acnes treatment induces IFN- $\gamma-$ producing Th1 cells in the liver by synergistic action of IL-12 and IL-18 (19). Although $\mathrm{CD}^{+} \mathrm{CD}^{-} \mathrm{NK} 1.1^{-} \mathrm{T}$ cells are reported to produce high amounts of IFN- $\gamma$ (19), our results demonstrated that $P$. acnes-primed liver $\mathrm{CD}^{+}{ }^{+} \mathrm{T}$ cells were characterized by Th1 type cells (Fig. $6 A$ ). Th1 polarization in the liver is essential to complete the priming process and to develop subsequent severe liver injury. Moreover, we demonstrated that $\mathrm{T}$ lymphocytes were also involved even in the eliciting phase (Fig. $4 A$ ). Contrary to the Th1 polarization by $P$. acnes priming, it is complicated to describe the phenotype of LPS-induced $\mathrm{CD}^{+} \mathrm{T}$ cells during the eliciting phase. Although sorted liver $\mathrm{CD}^{+} \mathrm{T}$ cells obtained at the eliciting phase are contaminated with preexisting Th1 cells, these cells produced higher levels of both IL- 4 and IFN- $\gamma$ (Fig. 6 A). Anti-TARC treatment downregulated IL-4 production, whereas IFN- $\gamma$ production was relatively upregulated among the sorted cells (Fig. 6 B). These results suggest that IL-4-producing Th2 but not Th1 type $\mathrm{CD}^{+} \mathrm{T}$ cells were relatively diminished by anti-TARC treatment. Furthermore, anti-TARC $\mathrm{mAb}$ reduced serum IL-4 levels while serum IFN- $\gamma$ levels persisted (data not shown), supporting the notion that TARC recruited Th2 type cells at the eliciting phase.

Recent investigations have revealed that CCR5 is preferentially expressed in Th1 cells, whereas CCR3 and CCR 4 are selective for $\mathrm{Th} 2$ cells $(3,6,11,12,24)$. Although liver $\mathrm{CD}^{+} \mathrm{T}$ cells predominantly expressed CCR 5 mRNA during the priming phase, the expression level of CCR5 was decreased gradually after elicitation by LPS (Fig. $5 A$ ). Since $P$. acnes treatment polarizes liver microenvironment toward Th1, CCR5 was presumably expressed by Th1 cells in agreement with previous reports $(3,6,11,12)$. In fact, MIP- $1 \alpha$, which is a ligand for CCR5, mRNA was detectable at high levels in the liver during the priming phase, and the expression levels were maintained during the eliciting phase (data not shown). On the other hand, among CXC chemokines, monokine induced by IFN- $\gamma$ (Mig) and IFN- $\gamma$-inducible protein (IP-10), which are considered to be selective for activated T lymphocytes (3-5), mRNAs were also expressed at high levels in the liver during the priming phase, and the expression levels were promptly decreased after elicitation by LPS (data not shown). Furthermore, liver $\mathrm{CD}^{+}{ }^{+} \mathrm{T}$ cells also expressed CXCR3 mRNA, the specific receptor for Mig and IP-10, during the priming phase, and the expression levels were also decreased gradually during the eliciting phase (Fig. $5 \mathrm{~A}$ ). Since Mig and IP-10 are reported to be induced by IFN- $\gamma$ (4), IL-12- and IL-18-induced IFN- $\gamma$ potentially upregulated Mig and IP-10 after P. acnes treatment, then acted on CXCR3-expressing T cells to further recruit Th1 type $\mathrm{CD}^{+} \mathrm{T}$ cells into the liver during the priming phase.

In contrast, liver $\mathrm{CD}^{+} \mathrm{T}$ cells expressed higher levels of CCR 4 mRNA after elicitation by LPS (Fig. $5 A$ ). Therefore, newly migrated $\mathrm{CD}^{+} \mathrm{T}$ cells arriving at the eliciting phase are 
apparently predominated by CCR4-expressing cells. AntiTARC treatment selectively reduced CCR4 expression (Fig. 5 $B)$. These patterns are analogous to those observed for IL-4 production by liver $\mathrm{CD}^{+} \mathrm{T}$ cells. Hence, CCR4 seems to be preferentially expressed in IL-4-producing Th2 type murine $\mathrm{CD} 4^{+} \mathrm{T}$ cells in vivo. Although CCR3 is reported to be selective for Th2 cells (24), liver CD4 ${ }^{+} \mathrm{T}$ cells did not express CCR3 mRNA in either the priming phase or the eliciting phase (data not shown). Moreover, eotaxin mRNA, which is a ligand for CCR3, was not detectable in the liver (data not shown).

Although the recruitment of CCR4-expressing $\mathrm{CD}^{+} \mathrm{T}$ cells into the liver by TARC seems to be a key phenomenon in inducing liver injury, the protective effects of anti-TARC $\mathrm{mAb}$ on both lethality and serum ALT levels were not complete (Fig. 3, $A$ and $B$ ). Another recently identified $\mathrm{CC}$ chemokine, $\mathrm{MDC}$, is also a ligand for CCR4 (10), and MDC mRNA was detected in the liver after elicitation by LPS with similar patterns as for TARC mRNA expression (data not shown). In addition, anti-TARC mAb could not completely reduce CCR4 expression in liver $\mathrm{CD}^{+}$cells (Fig. $5 \mathrm{~B}$ ), suggesting that MDC might also recruit CCR4-expressing $\mathrm{CD}^{+} \mathrm{T}$ cells into the liver. However, a neutralizing Ab against murine MDC has not been produced yet, hence the contribution of MDC could not be adequately established in this report.

The Fas-FasL pathway constitutes a major mechanism of $\mathrm{T}$ cell-mediated cytotoxicity (25), and is involved in liver injury $(14,16,26)$. LPS-induced CD $4^{+} \mathrm{T}$ cells expressed high levels of FasL mRNA (data not shown), whereas $P$. acnes-induced $\mathrm{CD}^{+} \mathrm{T}$ cells did not. Therefore, FasL-expressing $\mathrm{CD}^{+} \mathrm{T}$ cells may act as effector cells and kill Fas-expressing hepatocytes. Since anti-TARC treatment reduced FasL expression (data not shown) in $\mathrm{CD}^{+} \mathrm{T}$ cells, TARC might also be involved in activation of liver $\mathrm{CD}^{+}{ }^{+} \mathrm{T}$ cells. Although FasL is generally considered to be expressed on Th1 cells but not Th2 cells (27), Th2 cells are also capable of inducing apoptosis under some conditions (28). In this model, it is not easy to determine which subset of Th cells critically expresses FasL because sorted CD $4^{+} \mathrm{T}$ cells contained both Th1 and Th 2 cells.
Contrary to the reduction of TNF- $\alpha$ mRNA expression in the liver by anti-TARC treatment (Fig. $3 C$ ), anti-TARC mAb did not affect the serum TNF- $\alpha$ levels (data not shown). Thus, anti-TARC mAb has only local effects to cause liver injury. Hence, the immune interactions between TARC-producing macrophages and/or possibly dendritic cells present in granulomas and LPS-induced effector T cells may be a key factor in causing massive liver injury. Moreover, anti-TARC treatment also reduced the number of liver NKT $\left(\mathrm{NK} 1.1^{+} \mathrm{CD} 3 \epsilon^{\text {high }}\right.$ population) and $\mathrm{CD}^{+} \mathrm{T}$ cells (Fig. 4, $C$ and $D$ ) which are potentially effector cells $(29,30)$. Reduction in these populations may not be a direct effect of anti-TARC mAb because CCR4 mRNA was not detectable in NKT or $\mathrm{CD}^{+} \mathrm{T}$ cells. One possibility is that the reduction in these $\mathrm{T}$ killer cells may be dependent on sequential effects of anti-TARC mAb in reducing the recruitment of $\mathrm{CD}^{+} \mathrm{T}$ cells, thus diminishing the immune responses between antigen-presenting cells and Th2 type CD $4^{+}$ $\mathrm{T}$ cells. Therefore, anti-TARC treatment reduced the number of effector cells such as FasL-expressing $\mathrm{CD}^{+} \mathrm{T}$ cells, NKT cells, and $\mathrm{CD}^{+} \mathrm{T}$ cells, resulting in a marked reduction in TNF- $\alpha$ and FasL expression in the liver (Fig. $3 C$ ). These results may account for the protective effect of anti-TARC $\mathrm{mAb}$ in this liver injury model.

Based on these observations, we summarize the role of chemokines and chemokine receptors in this bacteria-induced liver injury model in Fig. 7. Our studies clearly indicate an important role for TARC at the eliciting phase. In this model, "priming" is also an essential process preparatory to sequential exacerbation induced by LPS challenge. Indeed, liver injury can be prevented by regulating the priming responses (14-18). However, the priming process is clinically unavoidable. It is more important to minimize the impairment boosted by the secondary eliciting process. In this model, migration of Th2 type $\mathrm{CD}^{+}{ }^{+} \mathrm{T}$ cells in response to TARC-producing granuloma-forming cells is a key phenomenon in causing sequential massive liver injury. In vivo administration of $\mathrm{mAb}$ against TARC is effective even after the priming process is completed. Our finding that anti-TARC mAb prevents the subsequent le-

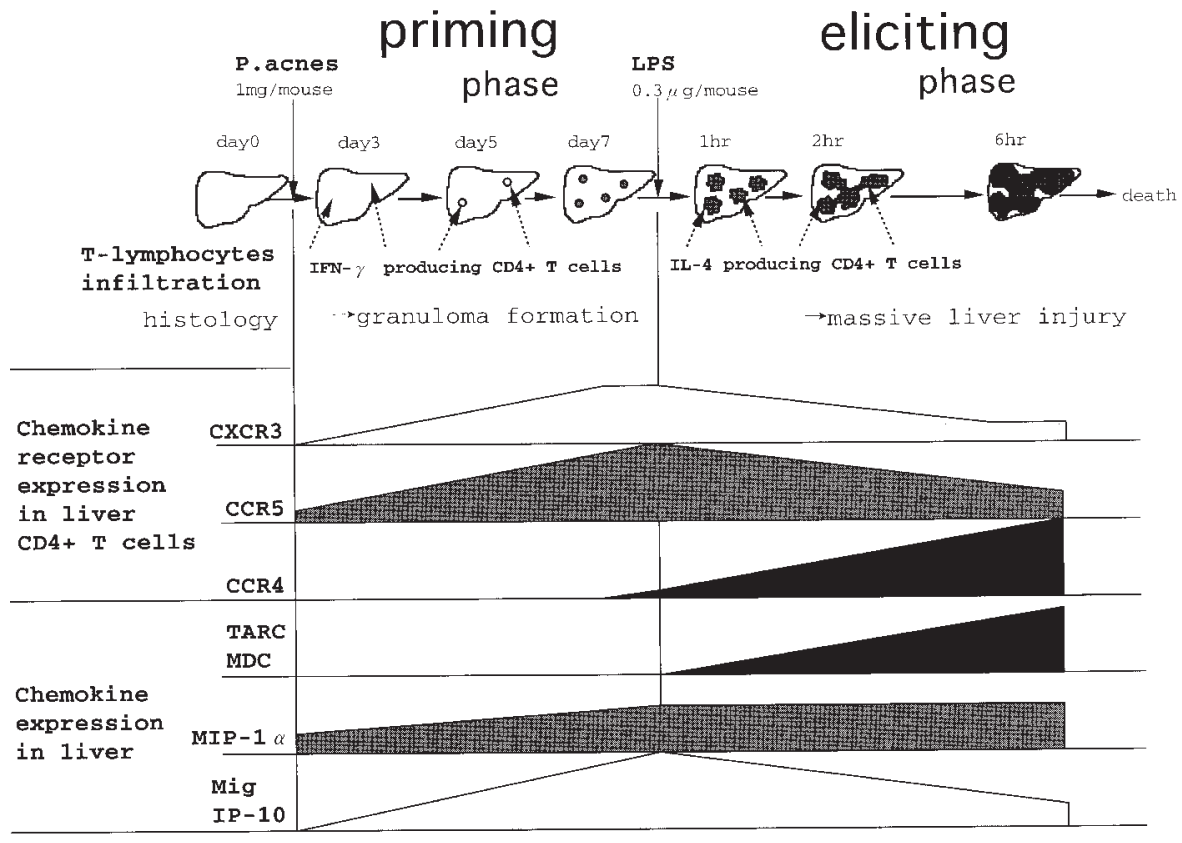

Figure 7. Chemokines and chemokine receptors in the P. acnes- and LPS-induced murine liver injury model. 
thal liver injury may be beneficial for development of new therapeutic approaches for human diseases, including FHF and possibly various other Th2-mediated disease processes.

\section{Acknowledgments}

We are very grateful to Drs. Joost J. Oppenheim (National Cancer Institute, Frederick, MD) and Christian Vestergaard for review before submission. We thank Prof. M. Naito and Dr. G. Hasegawa (Second Department of Pathology, Niigata University School of Medicine, Niigata, Japan) for advice on immunohistochemistry. We thank Mr. S. Fujita for animal surgical assistance.

\section{References}

1. Butcher, E.C., and L.J. Picker. 1996. Lymphocyte homing and homeostasis. Science. 272:60-66.

2. Austrup, F., D. Vestweber, E. Borges, M. Lohning, R. Brauer, U. Herz, H. Renz, R. Hallmann, A. Scheffold, A. Radbruch, and A. Hamann. 1997. Pand E-selectin mediate recruitment of T-helper-1 but not T-helper- 2 cells into inflamed tissues. Nature. 385:81-83. 568

3. Baggiolini, M. 1998. Chemokines and leukocyte traffic. Nature. 392:565-

4. Farber, J.M. 1997. Mig and IP-10 chemokines that target lymphocytes. J. Leukoc. Biol. 61:246-257.

5. Qin, S., J.B. Rottman, P. Myers, N. Kassam, M. Weinblatt, M. Loetscher, A.E. Koch, B. Moser, and C.R. Mackay. 1998. The chemokine receptors CXCR3 and CCR5 mark subsets of T cells associated with certain inflammatory reactions. J. Clin. Invest. 101:746-754.

6. Loetscher, P., M. Uguccioni, L. Bordoli, M. Baggiolini, B. Moser, C. Chizzolini, and J.-M. Dayer. 1998. CCR5 is characteristic of Th1 lymphocytes. Nature. 391:344-345.

7. Yoshie, O., T. Imai, and H. Nomiyama. 1997. Novel lymphocyte-specific CC chemokines and their receptors. J. Leukoc. Biol. 62:634-644.

8. Imai, T., T. Yoshida, M. Baba, M. Nishimura, M. Kakizaki, and O. Yoshie. 1996. Molecular cloning of a novel T cell-directed CC chemokine expressed in thymus by signal sequence trap using Epstein-Barr virus vector. $J$. Biol. Chem. 271:21514-21521.

9. Imai, T., M. Baba, M. Nishimura, M. Kakizaki, S. Takagi, and O. Yoshie. 1997. The T cell-directed CC chemokine TARC is a highly specific biological ligand for CC chemokine receptor 4. J. Biol. Chem. 272:15036-15042.

10. Imai, T., D. Chantry, C.J. Raport, C.L. Wood, M. Nishimura, R. Godiska, O. Yoshie, and P.W. Gray. 1998. Macrophage-derived chemokines is a functional ligand for the CC chemokine receptor 4. J. Biol. Chem. 273:17641768 .

11. Bonecchi, R., G. Bianchi, P.P. Bordignon, D. D'Ambrosio, R. Lang, A. Borsatti, S. Sozzani, P. Allavena, P.A. Gray, A. Mantovani, and F. Sinigaglia. 1998. Differential expression of chemokine receptors and chemotactic responsiveness of type 1 T helper cells (Th1s) and Th2s. J. Exp. Med. 187:129-134.

12. Sallusto, F., D. Lenig, C.R. Mackay, and A. Lanzavecchia. 1998. Flexible programs of chemokine receptor expression on human polarized T helper 1 and 2 lymphocytes. J. Exp. Med. 187:875-883.

13. Galle, P.R., W.J. Hofmann, H. Walczak, H. Schaller, G. Otto, W. Stremmel, P.H. Krammer, and L. Runkel. 1995. Involvement of the CD95 (APO-1/ Fas) receptor and ligand in liver damage. J. Exp. Med. 182:1223-1230.

14. Tsuji, H., A. Harada, N. Mukaida, Y. Nakanuma, H. Bluethmann, S. Kaneko, K. Yamakawa, S. Nakamura, K. Kobayashi, and K. Matsushima. 1997.
Tumor necrosis factor receptor p55 is essential for intrahepatic granuloma formation and hepatocellular apoptosis in a murine model of bacterium-induced fulminant hepatitis. Infect. Immun. 65:1892-1898.

15. Nagakawa, J., I. Hishinuma, K. Hirota, K. Miyamoto, T. Yamanaka, K. Tsukidate, K. Katayama, and I. Yamatsu. 1990. Involvement of tumor necrosis factor-alpha in the pathogenesis of activated macrophage-mediated hepatitis in mice. Gastroenterology. 99:758-765.

16. Tsutsui, H., K. Matsui, N. Kawada, Y. Hyodo, N. Hayashi, H. Okamura, K. Higashino, and K. Nakanishi. 1997. IL-18 accounts for both TNF- $\alpha$ and Fas ligand-mediated hepatotoxic pathway in endotoxin-induced liver injury in mice. J. Immunol. 159:3961-3967.

17. Tanaka, Y., K. Kobayashi, A. Takahashi, I. Arai, S. Higuchi, S. Otomo, S. Habu, and T. Nishimura. 1993. Inhibition of inflammatory liver injury by a monoclonal antibody against lymphocyte function-associated antigen-1. J. Immunol. 151:5088-5095.

18. Tanaka, Y., A. Takahashi, K. Watanabe, K. Takayama, T. Yahata, S. Habu, and T. Nishimura. 1996. A pivotal role of IL-12 in Th1-dependent mouse liver injury. Int. Immunol. 8:569-576.

19. Matsui, K., T. Yoshimoto, H. Tsutsui, Y. Hyodo, N. Hayashi, K. Hiroishi, N. Kawada, H. Okamura, K. Nakanishi, and K. Higashino. 1997. Propionibacterium acnes treatment diminishes CD41NK1.11 T cells but induces type $1 \mathrm{~T}$ cells in the liver by induction of IL-12 and IL-18 production from Kupffer cells. J. Immunol. 159:97-106.

20. Moriyama, H., T. Yamamoto, H. Takatsuka, H. Umezu, K. Tokunaga, T. Nagano, M. Arakawa, and M. Naito. 1997. Expression of macrophage colony-stimulating factor and its receptor in hepatic granulomas of Kupffer-celldepleted mice. Am. J. Pathol. 150:2047-2060.

21. Heid, C.A., J. Stevens, K.J. Livak, and P.M. Williams. 1996. Real time quantitative PCR. Genome Res. 6:986-994.

22. Watanabe, H., K. Ohtsuka, M. Kimura, Y. Ikarashi, K. Ohmori, A Kusumi, T. Ohteki, S. Seki, and T. Abo. 1992. Details of an isolation method for hepatic lymphocytes in mice. J. Immunol. Methods. 146:145-154.

23. Zhang, Y., N. Mukaida, J.B. Wang, A. Harada, M. Akiyama, and K. Matsushima. 1997. Induction of dendritic cell differentiation by granulocytemacrophage colony-stimulating factor, stem cell factor, and tumor necrosis factor $\alpha$ in vitro from lineage phenotype-negative ${\mathrm{c}-k i t^{+}}$murine hematopoietic progenitor cells. Blood. 90:4842-4853.

24. Sallusto, F., C.R. Mackay, and A. Lanzavecchia. 1997. Selective expression of the eotaxin receptor CCR3 by human T helper 2 cells. Science. 277: 2005-2007.

25. Lowin, B., M. Hahne, C. Mattmann, and J. Tschopp. 1994. Cytolytic T-cell cytotoxicity is mediated through perforin and Fas lytic pathways. Nature. 370:650-652.

26. Ogasawara, J., R. Watanabe-Fukunaga, M. Adachi, A. Matsuzawa, T. Kasugai, Y. Kitamura, N. Itoh, T. Suda, and S. Nagata. 1993. Lethal effect of the anti-Fas antibody in mice. Nature. 364:806-809.

27. Ramsdell, F., M.S. Seaman, R.E. Miller, K.S. Picha, M.K. Kennedy, and D.H. Lynch. 1994. Differential ability of Th1 and Th2 cells to express Fas ligand and to undergo activation-induced cell death. Int. Immunol. 6:1545-1553.

28. Watanabe, N., H. Arase, K. Kurasawa, I. Iwamoto, N. Kayagaki, H. Yagita, K. Okumura, S. Miyatake, and T. Saito. 1997. Th1 and Th2 subsets equally undergo Fas-dependent and -independent activation-induced cell death. Eur. J. Immunol. 27:1858-1864.

29. Takahashi, M., K. Ogasawara, K. Takeda, W. Hashimoto, H. Sakihara, K. Kumagai, R. Anzai, M. Satoh, and S. Seki. 1996. LPS induces NK1.11 $\alpha \beta$ T cells with potent cytotoxicity in the liver of mice via production of IL-12 from Kupffer cells. J. Immunol. 156:2436-2442.

30. Ando, K., T. Moriyama, L.G. Guidotti, S. Wirth, R.D. Schreiber, H.J. Schlicht, S. Huang, and F.V. Chisari. 1993. Mechanisms of class I restricted immunopathology. A transgenic mouse model of fulminant hepatitis. J. Exp. Med. 178:1541-1554. 